\title{
Sexual dimorphism in adult Little Stints (Calidris minuta) revealed by DNA sexing and discriminant analysis
}

\author{
Aleksandra Niemc ${ }^{\text {Corresp., }}{ }^{1}$ ， Magdalena Remisiewicz ${ }^{1,2}$, Joel Avni ${ }^{3}$, Les G. Underhill ${ }^{2}$ \\ 1 Bird Migration Research Station, Faculty of Biology, University of Gdańsk, Gdańsk, Poland \\ 2 Animal Demography Unit, Department of Biological Sciences, University of Cape Town, Cape Town, South Africa \\ 3 Bird's-Eye View Productions, Kommetjie, South Africa \\ Corresponding Author: Aleksandra Niemc \\ Email address: aleksandra.niemc@phdstud.ug.edu.pl
}

Background. The sex of an individual organism plays such an important role in its life cycle that researchers must know a bird's sex to interpret key aspects of its biology. Sexes of dimorphic species can be easily distinguished, but sexing monomorphic bird species often requires expensive and timeconsuming molecular methods. The Little Stint (Calidris minuta) is a numerous species, monomorphic in plumage but showing a small degree of reversed sexual size dimorphism. Females are larger than males but the ranges of their measurements overlap, making Little Stints difficult to sex in the field. Our aim was to develop reliable sexing criteria for Little Stints in different stages of primary moult during their stay on the non-breeding grounds in South Africa using DNA-sexed individuals and discriminant function analysis.

Methods. We caught 348 adult Little Stints in 2008-2016 on their non-breeding grounds at Barberspan Bird Sanctuary. To molecularly identify the birds' sex we used P2/P8 primers and DNA isolated from blood samples collected in the field. We used Storer's dimorphism index to assess the degree of sexual size dimorphism. Then we divided our sample into two groups: before or during and after primary moult. For each group we developed two functions: one using wing length only and the other a combination of morphometric features including wing, tarsus and total head length. Then we used a stepwise procedure to check which combination of measurements best discriminated sexes. To validate our result we used a jack-knife cross-validation procedure and Cohen-kappa statistics.

Results. All the morphometric features we measured were bigger in DNA-sexed females than in males. Birds with fresh primaries had on average $2.3 \mathrm{~mm}$ longer wings than those with worn primaries. A discriminant function using wing length $\left(D_{1}\right)$ correctly sexed $78.8 \%$ of individuals before moult, and a stepwise analysis showed that a combination of wing length and tarsus $\left(D_{2}\right)$ correctly identified the sex of $82.7 \%$ of these birds. For birds with freshly moulted primaries a function using wing length $\left(D_{3}\right)$ correctly classified $83.4 \%$ of the individuals, and a stepwise analysis revealed that wing and total head length $\left(D_{4}\right)$ classified $84.7 \%$.

Discussion. Sexual size differences in Little Stints might be linked to their phylogenetics and breeding biology. Females are bigger, which increases their fecundity; males are smaller, which increases their manoeuverability during display flights and hence their mating success. Little Stints show an extreme lack of breeding site fidelity so we did not expect a geographical cline in their biometrics. Sexing criteria available for Little Stints in the literature were developed using museum specimens, which often shrink, leading to misclassification of live birds. The sexing criteria we developed can be used for studies on Little Stints at their non-breeding grounds and on past data, but should be applied cautiously because of the overlapping ranges. 


\section{Sexual dimorphism in adult Little Stints (Calidris minuta) 2 revealed by DNA sexing and discriminant analysis}

3 Aleksandra Niemc ${ }^{1}$, Magdalena Remisiewicz ${ }^{1,2}$, Joel Avni ${ }^{3}$, Les G. Underhill²

4

$5 \quad{ }^{1}$ Bird Migration Research Station, Faculty of Biology, University of Gdańsk, Gdańsk, Poland

$6{ }^{2}$ Animal Demography Unit, Department of Biological Sciences, University of Cape Town, Cape

7 Town, South Africa

$8 \quad{ }^{3}$ Bird's-Eye View Productions, Kommetjie, South Africa

9

10 Corresponding Author:

11 Aleksandra Niemc

12 University of Gdańsk, Faculty of Biology, ul. Wita Stwosza 59, C306, Gdańsk, 80-308, Poland

13 Email address: aleksandra.niemc@phdstud.ug.edu.pl 
14

\section{Abstract:}

Background. The sex of an individual organism plays such an important role in its life cycle that researchers must know a bird's sex to interpret key aspects of its biology. Sexes of dimorphic species can be easily distinguished, but sexing monomorphic bird species often requires expensive and time-consuming molecular methods. The Little Stint (Calidris minuta) is a numerous species, monomorphic in plumage but showing a small degree of reversed sexual size dimorphism. Females are larger than males but the ranges of their measurements overlap, making Little Stints difficult to sex in the field. Our aim was to develop reliable sexing criteria for Little Stints in different stages of primary moult during their stay on the non-breeding grounds in South Africa using DNA-sexed individuals and discriminant function analysis.

Methods. We caught 348 adult Little Stints in 2008-2016 on their non-breeding grounds at Barberspan Bird Sanctuary. To molecularly identify the birds' sex we used P2/P8 primers and DNA isolated from blood samples collected in the field. We used Storer's dimorphism index to assess the degree of sexual size dimorphism. Then we divided our sample into two groups: before or during and after primary moult. For each group we developed two functions: one using wing length only and the other a combination of morphometric features including wing, tarsus and total head length. Then we used a stepwise procedure to check which combination of measurements best discriminated sexes. To validate our result we used a jack-knife crossvalidation procedure and Cohen-kappa statistics.

Results. All the morphometric features we measured were bigger in DNA-sexed females than in males. Birds with fresh primaries had on average $2.3 \mathrm{~mm}$ longer wings than those with worn primaries. A discriminant function using wing length $\left(\mathrm{D}_{1}\right)$ correctly sexed $78.8 \%$ of individuals before moult, and a stepwise analysis showed that a combination of wing length and tarsus $\left(\mathrm{D}_{2}\right)$ correctly identified the sex of $82.7 \%$ of these birds. For birds with freshly moulted primaries a function using wing length $\left(\mathrm{D}_{3}\right)$ correctly classified $83.4 \%$ of the individuals, and a stepwise analysis revealed that wing and total head length $\left(\mathrm{D}_{4}\right)$ classified $84.7 \%$.

Discussion. Sexual size differences in Little Stints might be linked to their phylogenetics and breeding biology. Females are bigger, which increases their fecundity; males are smaller, which increases their manoeuverability during display flights and hence their mating success. Little 
43 Stints show an extreme lack of breeding site fidelity so we did not expect a geographical cline in 44 their biometrics. Sexing criteria available for Little Stints in the literature were developed using museum specimens, which often shrink, leading to misclassification of live birds. The sexing criteria we developed can be used for studies on Little Stints at their non-breeding grounds and on past data, but should be applied cautiously because of the overlapping ranges.

\section{Introduction}

An individual's sex is one of the most important factors shaping its biology. Male and female birds are subject to sex-specific selection pressures that entail differences in their biology, including migration strategies (Remisiewicz \& Wennerberg, 2006; Jakubas et al., 2014), population structure (Nebel, 2006), foraging behaviour (Mathot \& Elner, 2004; Nebel, 2005), moult (Barshep et al., 2013) and physiology (Kulaszewicz, Wojczulanis-Jakubas \& Jakubas, 2015). Differences in the biology of males and females lead to diverging body sizes (Fairbairn, 2007) and are expected to emerge if selection for a character is stronger in one sex than in the other (Székely, Lislevand \& Figuerola, 2007). Sexing monomorphic birds is difficult in the field, but can be done with molecular methods (Dubiec \& Zagalska-Neubauer, 2006) using DNA isolated from blood samples (Owen, 2011), feathers (Bello, Francino \& Sánchez, 2001) or buccal swabs (Handel et al., 2006); however those methods often stress the birds and are expensive. For species in which males and females are monomorphic in plumage but show sexual size dimorphism (SSD) the sex can often be identified using morphometrics (DechaumeMoncharmont, Monceau \& Cézilly, 2011). In such cases the degree of sexual size dimorphism is crucial because in some species measurements overlap between sexes, which might lead to misidentification (Jiménez, García-Lau \& Gonzalez, 2015). Discriminant function analysis enables observers to use a combination of morphological measurements to predict the sex of a bird with a certain probability (Tabachnick \& Fidell, 2007). However, the efficiency of this method depends on the accuracy of the measurements, which suffers if researchers are not calibrated with each other or if wing length is measured on feathers in different stages of wear (Dechaume-Moncharmont, Monceau \& Cézilly, 2011). Our study focuses on Little Stints, which are monomorphic in plumage but exhibit a small degree of sexual size dimorphism, with the females slightly larger than the males (del Hoyo, Elliott \& Sargatal, 1996). The ranges of their measurements overlap, which impedes sexing them in the field (Prater, Marchant \& Vuorinen, 
1977). Sexing criteria for Little Stints in the literature are usually based on small samples or on museum specimens, which are known to shrink (Prater, Marchant \& Vuorinen, 1977).

We aimed to develop reliable sexing criteria for adult Little Stints by discriminant functions that accounted for the stage of wear of their primaries using measurements of DNAsexed individuals spending the non-breeding season in South Africa. We suggest that these discriminant functions serve as a useful tool, after adjustment to local measurement routines, for other researchers studying Little Stints at various stages of their life cycle.

\section{Materials \& methods}

\section{Species and study area}

The Little Stint is a long-distance migrant wader, which breeds in the Eurasian tundra and spends the non-breeding season from the Mediterranean coasts south throughout sub-Saharan Africa to South Africa in the south and southwestern Asia in the east (del Hoyo, Elliott \& Sargatal, 1996; Tulp et al., 2002; Round et al., 2012). A few individuals are also found further east along the East Asian-Australasian Flyway (Tomkovich, Chih-Yuan \& Liu, 2009). Little Stint is a numerous species with an estimated world population of 1,500,000 individuals, a Least Concern conservation status and an increasing population trend (Delany \& Scott, 2006; BirdLife International, 2016). Most Little Stints leave the non-breeding grounds and attempt breeding at the end of their first year; but a few stay in South Africa over the austral winter (Underhill, 1997; Underhill et al., 1999). Immature Little Stints can be distinguished from adults by the retained chestnut-fringed inner median coverts, which in adults are pale grey-brown tipped whitish (Prater, Marchant \& Vuorinen, 1977). After arrival at the non-breeding grounds immature and adult birds undergo a complete moult, including the replacement of remiges. They complete this moult in January-March, after which the immatures become indistinguishable from the adults (Prater, Marchant \& Vuorinen, 1977).

We caught Little Stints at Barberspan Bird Sanctuary $\left(26^{\circ} 33^{\prime} \mathrm{S}, 2^{\circ} 36^{\prime} \mathrm{E}\right.$; North West Province, South Africa, Fig. 1). This reserve is centered on a shallow alkaline lake whose area varies from 257 ha to 2000 ha, depending on rainfall (Milstein, 1975; Barnes, 1998). Lake Barberspan is fed by the Harts River. In the austral winter and during droughts it becomes the only permanent waterbody in the surrounding farmland, which makes it an important stopover, 
102 moulting and non-breeding destination for waterbirds, including Palearctic migrants (Barnes,

103 1998; Lipshutz et al., 2011; Remisiewicz \& Avni, 2011). Barberspan Bird Sanctuary is a

104 Wetland of International Importance in terms of the Ramsar Convention and is an Important Bird

105 Area according to Bird Life International (Cowan, 1995; Barnes, 1998; Remisiewicz \& Avni, 106 2011).

\section{Data collection}

108 During September-April in 2008-2016 we captured 348 adult Little Stints using walk-in traps 109 (Busse \& Meissner, 2015) and mist nets. We ringed and measured each bird. Measurements 110 included: bill length (from the feather line to the bill tip), total head length (from the back of the 111 skull to the bill tip) and tarsus length (from the tarsal joint to the distal end of the tarso112 metatarsus), taken with callipers of $0.1 \mathrm{~mm}$ accuracy, and wing length (flattened and straightened 113 wing, as in Evans (1986) and Prater, Marchant \& Vuorinen (1977)), tarsus-plus-toe (Anderson, 1141975 ) taken to the nearest $1 \mathrm{~mm}$ with a ruler, and body mass to $1 \mathrm{~g}$ or $0.1 \mathrm{~g}$ in different years 115 (weighed with an electronic scale). We used only morphological measurements taken by MR 116 (SAFRING ringing permit 1454), as recommended in Henry et al. (2015) because measurements 117 taken by different ringers can reduce the accuracy of sex discrimination. We also took blood 118 samples from a brachial vein (Owen, 2011) from all ringed Little Stints and preserved the 119 samples in 96\% ethanol for DNA sexing. Only trained, experienced team members handled the 120 birds and took the blood samples to ensure safety standards. All the procedures were approved 121 by the management of Barberspan Bird Sanctuary, under permits from SAFRING and the 122 Department of Rural, Environmental and Agricultural Development, North West Provincial 123 Government, South Africa.

124

125

126

127

128

129 130

\section{Molecular sex identification}

We isolated DNA from blood samples using the Blood Mini Kit (A\&A Biotechnology, Poland). The next step was PCR with the pair of P2 and P8 primers (Griffiths et al., 1998) using a modified protocol. Total volume of PCR was $20 \mu 1$, the reaction mix included: $7.5 \mu 1$ REDTaq ${ }^{\circledR}$ ReadyMix $^{\mathrm{TM}}$ (Sigma Aldrich), $3.5 \mu$ l of water, $1 \mu 1 \mathrm{MgCl}_{2}, 1 \mu 1 \mathrm{P} 2$ primer $(10 \mu \mathrm{M}), 1 \mu 1 \mathrm{P} 8$ primer $(10 \mu \mathrm{M})$ and $2 \mu \mathrm{l}$ of the DNA sample. For PCR amplifications we used an Eppendorf Mastercycler with this thermic profile: an initialisation at $94^{\circ} \mathrm{C}$ for 2 minutes, 40 cycles of 
131 denaturation at $94^{\circ} \mathrm{C}$ for 30 seconds, 40 cycles of annealing at $50^{\circ} \mathrm{C}$ for 30 seconds and 40 cycles

132 of elongation at $72^{\circ} \mathrm{C}$ for 2 minutes, ending with a final elongation at $72^{\circ} \mathrm{C}$ for 5 minutes. This

133 method is based on the amplification of chromo-helicase-DNA-binding (CHD) genes found on

134 avian sex chromosomes. The CHD-Z gene (ca 370 bp) is located on the $\mathrm{Z}$ chromosome,

135 therefore it is present in both sexes. The CHD-W gene (ca $390 \mathrm{bp}$ ) occurs only on chromosome

$136 \mathrm{~W}$, therefore it is unique to females (Griffiths et al., 1998). We separated the products of PCR

137 with electrophoresis on $3.5 \%$ agarose gel $(75 \mathrm{~V}, 120 \mathrm{~min})$ stained with ethidium bromide

138 (samples from 2008-2013) and Midori Green Advanced DNA Stain (NIPPON Genetics, samples

139 from 2013-2016). Products were visualised in UV light, one band was visible for males, which

140 indicated ZZ chromosomes, and two bands for females (ZW chromosomes). The method enabled

141 us to sex all birds sampled.

142 Statistical analysis

143 For each morphometric measurement we used Storer's dimorphism index (SDI) to assess the 144 degree of sexual size dimorphism in Little Stints (Storer, 1966), using the formula:

$$
\mathrm{SDI}=\frac{\text { mean } \$-\text { mean } \sigma^{x}}{\left(\text { mean } \sigma^{x}+\text { mean } \circ\right) * 0.5} * 100
$$

We compared all the morphometrics we had measured of males and females using the twosample $t$-test. Then we divided the birds into two groups: those before and those after primary moult, and compared the measurements of birds from these two groups. Birds caught in active moult were classified as "before moult" because they moult their outermost primary last. However, we did not measure wing length of any bird whose outermost primary was heavily damaged or if it was growing. For each group we used discriminant function analysis to determine the best set of measurements for sexing Little Stints with a two-fold approach. First, we used wing length alone as a discriminant factor. The second approach used a stepwise method including other measurements after conducting pairwise correlation of all the measurements. We used only one of a pair of correlated measurements at a time in the stepwise procedure to avoid multicollinearity. We did not include the body mass of Little Stints, because it changes during the non-breeding season during pre-migratory fuelling. The aim of producing two different discriminant functions for each group was to make these functions applicable for different data 
159 sets, because wing length is the most commonly taken measurement, in contrast to tarsus and

160

161

162

163

164

165

166

167

168

169

170

171

172

173

174

175

176

177

178

179

180

181

182

183

184

185

186

187

188

total head lengths. We present the discriminant functions developed using different sets of morphometrics in the Supplemental Information. All the assumptions of discriminant function analysis were met (Tabachnick \& Fidell, 2007), including the homogeneity of covariances (Box's M test), the homogeneity of variance (Levene's test), and the normal distributions of the measurements for males and females separately in each of the two groups. We confirmed no multicollinearity of the selected measurements ( $\mathrm{r}<0.50$ for all pairwise correlations). We computed prior classification probabilities from the group sizes because of the unequal number of males and females in our sample (Tabachnick \& Fidell, 2007). To validate our models we used a jack-knife procedure to assess the percentage of correctly sexed individuals by discriminant function analysis (Dechaume-Moncharmont et al. 2011). This cross-validation technique predicts the sex of each individual using a discriminant function calculated for all the birds except the individual being classified (Hair et al., 1995). We had unequal samples of males and females, so we assessed the effectiveness of our proposed functions by calculating Cohen's kappa statistic (Titus \& Mosher, 1984), which estimates the improvement made by the results of discriminant analysis over random chance: $0=$ no improvement over chance, $1=$ full compliance (Titus \& Mosher, 1984). The optimal cutting score was calculated as a weighted average of the group centroids (Hair et al., 1995). Statistical analyses were performed in IBM SPSS Statistics for Windows, version 22.0 (IBM Corp., Armonk, N.Y., USA). All tests were two-tailed and the accepted level of significance was $\mathrm{P}<0.05$.

\section{$\underline{\text { Results }}$}

\section{Morphological differences between the sexes}

We identified 185 males and 163 females using DNA sexing. Analysis of morphometrics and Storer's dimorphism index (SDI) also revealed sexual differences. On average females were bigger than males in all morphological measurements (Table 1). The most dimorphic features were respectively bill, wing and total head lengths (Table 1). In all our measurements birds before and after wing moult differed only in wing length $\left(\mathrm{t}_{311}=7.69, \mathrm{P}<0.001\right)$, which was on average $2.3 \mathrm{~mm}$ longer in those with fresh primaries after moult than in those before moult with worn primaries. We therefore conducted the discriminant analyses separately for these two groups. 
Some morphological measurements were correlated (correlation coefficients for males

190

191

192

193

194

195

196

197

198

199

200

201

202

203

204

205

206

207

208

209

210

211

212

213

214

215 and females between tarsus and tarsus-plus-toe were $r=0.73$ and $r=0.79$ and for culmen and total head length $\mathrm{r}=0.81$ and $\mathrm{r}=0.83$ ). We chose wing length, total head length (because it is less prone to errors than bill length measured to the feather line, which might be worn difficult to determine (Prater, Marchant \& Vuorinen, 1977)), and tarsus length as the best factors for discriminant analysis.

\section{Discriminant functions for adult Little Stints before primary moult}

Using measurements of 156 adult Little Stints (70 females and 86 males) taken before they had moulted their primaries, and using only wing length as a discriminant factor, we obtained the equation:

$$
\mathrm{D}_{1}=-47.496+0.484 \text { (wing) }
$$

which allowed us to correctly classify $78.8 \%$ of the birds. A jack-knife cross-validation procedure yielded the same success rate, and our random chance-corrected procedure showed that our proposed classification was $56.8 \%$ better than chance (kappa $=0.568 \pm 0.082 \mathrm{SE}, \mathrm{P}<$ 0.001). If $\mathrm{D}_{1}>0.17$, the bird was classified as a female, and if $\mathrm{D}_{1}<0.17$ as a male (Fig. 2)

In the stepwise procedure including three selected measurements (wing, tarsus and total head length), only the combination of wing and tarsus length was a significant discriminant factor. The best discriminant function we obtained was

$$
\mathrm{D}_{2}=-50.428+0.421 \text { (wing) }+0.420 \text { (tarsus) }
$$

This function correctly classified $82.7 \%$ of the birds and was more accurate than the previous equation. The cross-validation procedure correctly classified $80.8 \%$ of individuals and the classification was $65.1 \%$ better than chance (kappa $=0.651 \pm 0.081 \mathrm{SE}, \mathrm{P}<0.001) . \mathrm{If}_{2}>0.18$ then the individual was a female and if $\mathrm{D}_{2}<0.18$ it was a male (Fig. 3).

\section{Discriminant functions for adult Little Stints after primary moult}

The second group we analysed comprised 159 adult Little Stints (82 females and 77 males) with all new primaries after their complete post-breeding moult. The function obtained using only wing length was 


$$
\mathrm{D}_{3}=-52.184+0.520 \text { (wing) }
$$

217 This function correctly classified $83.4 \%$ of the individual birds, which was confirmed by the 218 cross-validation procedure. The proposed classification was $66.9 \%$ better than chance (kappa $=$ $2190.669 \pm 0.080 \mathrm{SE}, \mathrm{P}<0.001)$. When $\mathrm{D}_{3}>-0.038$ the individual was classified as a female, when $220 \mathrm{D}_{3}<-0.038$ as a male (Fig. 2).

221

222

The stepwise analysis revealed that the best discriminating combination of measurements was wing and total head length (THL), according to the equation

$$
\mathrm{D}_{4}=-59.310+0.445 \text { (wing) }+0.377(\mathrm{THL}) \text {. }
$$

This function correctly classified $84.7 \%$ of the individuals in the sample, which was the highest proportion of all the equations we present. The cross-validation procedure showed that the proposed equation was $84.1 \%$ correct and $69.4 \%$ better than chance (kappa $=0.694 \pm 0.080 \mathrm{SE}$, $\mathrm{P}<0.001$ ). If $\mathrm{D}_{4}>-0.041$ a Little Stint was classified as a female and if $\mathrm{D}_{4}<-0.041$ as a male (Fig. 3).

\section{$\underline{\text { Discussion }}$}

We showed that the female Little Stints were larger than the males, not only in wing length, as described earlier (Cramp \& Simmons, 1983; Prater, Marchant \& Vuorinen, 1977), but also in other body features, as indicated by Storer's dimorphism index (Table 1). Thus we recommend a combination of several measurements in discriminant functions as a useful tool in studies of sexual differences of this species. Such a size difference might benefit each sex in different ways, the females through increased fecundity and the males through higher mating success with smaller size, which we discuss.

Mean wing lengths based on the sexing criteria in Prater, Marchant \& Vuorinen (1977) and established by Tree (1974) are $95.9 \mathrm{~mm}$ for adult males and $99.5 \mathrm{~mm}$ for adult females, 1.5 $\mathrm{mm}$ and $1.7 \mathrm{~mm}$ shorter than our results (Table 1). The sexing criteria presented in Prater, Marchant \& Vuorinen (1977) were developed using museum specimens and thus subjected to shrinkage (Jenni \& Winkler, 1994). We compared our differences with the one obtained using a regression equation in Engelmoer et al. (1983), where: shrinkage $=0.006 *$ fresh wing-length $[\mathrm{mm}]+0.976$, which predicted shrinkage for both sexes of $1.6 \mathrm{~mm}$, similar to the difference we 
244 observed between the criteria in literature and for our sample. Moult and feather wear are important considerations when taking feathered measurements like wing length (Meissner, 2005; Jiménez, García-Lau \& Gonzalez, 2015), thus we propose different discriminant functions for birds before and after moult. During the non-breeding season all Little Stints should be carefully examined for moult because their outermost primary might still be growing. Measuring wing lengths of birds moulting P10 would underestimate wing length and could even cause misclassifications.

251

252

253

254

255

256

257

258

259

260

261

262

263

264

265

266

267

268

269

270

271

272

273

Sexual differences in the size of Little Stints might be closely related to their breeding biology. Male mating success is a strong form of sexual selection that affects their morphometrics. During the breeding season male Little Stints perform display flights, favouring smaller size to increase manoeuverability (Figuerola, 1999; Székely et al., 2000). The females’ bigger size might be connected with increasing fecundity, because Little Stints exhibit successive bigamy of both sexes. Females lay two clutches in a short period (Cramp \& Simmons, 1983; Hildén, 1983) and a larger body size allows them to compensate better for the increased energy expenditure of egg production (Jönsson \& Alerstam, 1990). Sexual differences in morphometrics cannot be explained by a division in parental care, because each clutch and brood is cared for by a single parent of either sex (Tulp et al., 2002). The patterns we observed are in line with Rensch's rule, which points out that sexual differences in body size are usually small when females are the larger sex (Rensch, 1950; Dale et al., 2007).

Small calidridine sandpipers, such as Western Sandpiper (Nebel, 2005) and Least Sandpiper (Nebel, 2006), exhibit substantial sexual differences in bill length, which is the most dimorphic morphometric in Little Stints (Table 1). Nebel \& Thompson (2011) show that sexual size dimorphism in calidrids is more distinct for trophic traits (e. g. bill length) than non-trophic traits, but those differences might be a result of their shared ancestry rather than natural or sexual selection.

A wide breeding range, such as that of the Little Stint, often results in a geographical variation in biometrics (Zwarts et al., 1996; Dmitrenok et al., 2007), which might distort a discriminant function analysis. We do not expect such differences in our study because Little Stints are an opportunistic species that show no natal philopatry or breeding-site fidelity and breed wherever they find favourable environmental conditions (Hildén, 1983; Underhill et al., 
274 1993; Tomkovich \& Soloviev, 1994). Their polygamous breeding system where males and

275 females both frequently have two partners enhances gene-flow in the population, limiting

276 geographical clines in the morphometrics of Little Stints.

\section{Conclusions}

278 DNA sexing remains the most reliable method for monomorphic species, but discriminant

279 functions are useful when researchers cannot collect or process DNA samples, get permits or

280 when sex identification is needed in field studies. The functions we developed can be applied to

281 measurements collected from Little Stints at their non-breeding grounds in the past and can

282 strengthen the analysis when an individual bird's sex must be known. To make our functions

283 more applicable for a wider range of researchers we present equations that can be used with

284 different standard morphological measurements and equations that consider the wear of primary

285 feathers. Our results are based on relatively large samples and all of the measurement were taken

286 by one ringer, but ringing teams should regularly calibrate all people taking measurements

287 (Dechaume-Moncharmont, Monceau \& Cézilly, 2011), which improves the accuracy of sexing

288 by discriminant functions. The functions we suggest should be applied cautiously to data from

289 other researchers because of the risk of misclassification, and should probably first be adjusted to

290 each study, considering possible differences in measuring routines with those of our team. These

291 functions should not be applied to Little Stints at their breeding grounds because their wing

292 morphometrics possibly are different after migration. We suggest that the application of these or

293 similar discriminant functions are a useful tool facilitating studies of differences in the biology of

294 the sexes at different stages of the life cycle, in Little Stints and in other species exhibiting small

295 sexual size dimorphism.

\section{Acknowledgements}

297 We thank the staff at Barberspan Bird Sanctuary for their help and for making us feel welcome.

298 We are grateful to all volunteers who helped to collect the data we used. We also thank Jacek

299 Mazur for drawing the map.

300 References:

301 Anderson A. 1975. A method of sexing Moorhens. Wildfowl 26:77-82. 
302

303

304

305

306

307

308

309

310

311

312

313

314

315

316

317

318

319

320

321

322

323

324

325

326

327

Barnes K. 1998. Important Bird Areas of the North West Province. The Important Bird Areas of Southern Africa: 93-122. Johannesburg: BirdLife South Africa.

Barshep Y, Underhill LG, Balachandran S, Pearson DJ. 2013. Conditions on the non-breeding areas affect primary moult strategy of the Curlew Sandpiper Calidris ferruginea. Ardea 101:13-22. DOI: http://dx.doi.org/10.5253/078.101.0114.

Bello N, Francino O, Sánchez A. 2001. Isolation of genomic DNA from feathers. Journal of Veterinary Diagnostic Investigation 13(2): 162-164.

BirdLife International. 2016. Calidris minuta. The IUCN Red List of Threatened Species 2016: e.T22693379A86624964. http://dx.doi.org/10.2305/IUCN.UK.20163.RLTS.T22693379A86624964.en. Downloaded on 14 May 2018.

Busse P, Meissner W. 2015. Bird Ringing Station Manual. Warsaw, Poland: De Gruyter Open Ltd.

Cowan GI. 1995. Wetlands of South Africa. Pretoria: Department of Environmental Affairs and Tourism.

Cramp S, Simmons KEL. 1983. Volume 3. In: The birds of the Western Palearctic. Handbook of the birds of Europe, the Middle East and North Africa. Oxford: Oxford University Press, $303-310$.

Dale J, Dunn PO, Figuerola J, Lislevand T, Székely T, Whittingham LA. 2007. Sexual selection explains Rensch's rule of allometry for sexual size dimorphism. Proceedings of the Royal Society 274:2971-2979. DOI: 10.1098/rspb.2007.1043.

Dechaume-Moncharmont F-X, Monceau K, Cézilly F. 2011. Sexing birds using discriminant function analysis: a critical appraisal. The Auk 128:78-86. DOI: 10.1525/auk.2011.10129.

Delany S, Scott D. 2006. Waterbird population estimates - fourth edition. Wetlands International, Wageningen, The Netherlands.

Dmitrenok M, Puglisi L, Demongin L, Gilbert G, Polak M, Bretagnolle V. 2007. Geographical variation, sex and age in Great Bittern Botaurus stellaris using coloration and 

morphometrics. Ibis 149:37-44. DOI: 10.1111/j.1474-919X.2006.00592.x.

329 330

331

332

333

334

335

336

337

338

339

340

341

342

Dubiec A, Zagalska-Neubauer M. 2006. Molecular techniques for sex identification in birds. Biological Letters 43:3-12.

Engelmoer M, Roselaar K, Boere GC, Nieboer E. 1983. Post-mortem changes in measurements of some waders. Ringing \& Migration 4:245-248. DOI: 10.1080/03078698.1983.9673814.

Evans PR. 1986. Correct measurement of the wing-length of waders. Wader Study Group Bulletin 48:11.

Fairbairn DJ. 2007. Introduction: the enigma of sexual size dimorphism. In Fairbairn, D.J., Blanckenhorn, W. \& Székely, T. (eds) Sex, Size and Gender Roles: Evolutionary Studies of Sexual Size Dimorphism:1-10. Oxford: Oxford University Press.

Figuerola J. 1999. A comparative study on the evolution of reversed size dimorphism in monogamous waders. Biological Journal of the Linnean Society 67: 1-18

Griffiths R, Double MC, Orr K, Dawson RJG. 1998. A DNA test to sex most birds. Molecular Ecology 7:1071-1075. DOI: 10.1046/j.1365-294x.1998.00389.x.

Hair JF Jr, Anderson RE, Tatham RL, Black WC. 1995. Multivariate data analysis. Prentice Hall, Upper Saddle River, NJ

Handel CM, Pajot LM, Talbot SL, Sage GK. 2006. Use of buccal swabs for sampling DNA from nestling and adult birds. Wildlife Society Bulletin 34:1094-1100. DOI: 10.2193/0091$7648(2006) 34$.

Henry L, Biquand V, Craig AJFK, Hausberger M. 2015. Sexing adult Pale-Winged Starlings using morphometric and discriminant function analysis. Plos One 10(9): e0135628. DOI: 10.1371/journal.pone.0135628.

Hildén O. 1983. Mating system and breeding biology of Little Stint Calidris minuta. Wader Study Group Bulletin 39:47.

del Hoyo J, Elliott A, Sargatal J. 1996. Volume 3. In: Handbook of the birds of the world. Barcelona: Lynx Edicions. 
354 Jakubas D, Wojczulanis-Jakubas K, Foucher J, Dziarska-Pałac J, Dugué H. 2014. Age and sex

355 differences in fuel load and biometrics of Aquatic Warblers Acrocephalus paludicola at an 356 autumn stopover site in the Loire Estuary (NW France). Ardeola 61:15-30. DOI:

357 10.13157/aria.61.1.2014.15.

358

359

360

361

362

363

364

365

366

367

368

369

370

371

372

373

374

375

376

377

378

379

380

Jenni L, Winkler R. 1994. Moult and ageing of European passerines. London: Academic Press.

Jiménez A, García-Lau I, Gonzalez A. 2015. Sex determination of Least Sandpiper (Calidris minutilla) and Western Sandpiper (Calidris mauri): comparing methodological robustness of two morphometric. Waterbirds 38:10-18. DOI: 10.1675/063.038.0103.

Jönsson PE, Alerstam T. 1990. The adaptive significance of parental role division and sexual size dimorphism in breeding shorebirds. Biological Journal of the Linnean Society 41: 301314.

Kulaszewicz I, Wojczulanis-Jakubas K, Jakubas D. 2015. Variation of the Savi's Warbler (Locustella luscinioides) leucocyte profiles and body condition in relation to age, sex and moult. Annales Zoologici Fennici 52:325-338. DOI: 10.5735/086.052.0507.

Lipshutz S, Remisiewicz M, Underhill LG, Avni J. 2011. Seasonal fluctuations in population size and habitat segregation of Kittlitz's Plover Charadrius pecuarius at Barberspan Bird Sanctuary, North West province, South Africa. Ostrich 82:207-215. DOI: 10.2989/00306525.2011.618245.

Mathot KJ, Elner RWR. 2004. Evidence for sexual partitioning of foraging mode in Western Sandpipers (Calidris mauri) during migration. Canadian Journal of Zoology 82:1035-1042. DOI: $10.1139 /$ Z04-080.

Meissner W. 2005. Sex determination of juvenile Dunlins migrating through the Polish Baltic region. Journal of Field Ornithology 76:368-372. DOI: 10.1648/0273-8570-76.4.368.

Milstein P le S. 1975. The biology of Barberspan, with special reference to the avifauna. Ostrich Supplement 10:1-74.

Nebel S. 2005. Latitudinal clines in bill length and sex ratio in a migratory shorebird: A case of resource partitioning? Acta Oecologica 28:33-38. DOI: 10.1016/j.actao.2005.02.002. 
381 Nebel S. 2006. Latitudinal clines in sex ratio, bill, and wing length in Least Sandpipers. Journal

382

383

384

385

386

387

388

389

390

391

392

393

394

395

396

397

398

399

400

401

402

403

404

405

406 of Field Ornithology 77:39-45. DOI: 10.1111/j.1557-9263.2006.00021.x.

Nebel S., Thompson GJ. 2011. The evolution of sexual bill-size dimorphism in shorebirds: a morphometric test of the resource partitioning hypothesis. Evolutionary Ecology Research $13: 35-44$.

Owen JC. 2011. Collecting, processing, and storing avian blood: A review. Journal of Field Ornithology 82:339-354. DOI: 10.1111/j.1557-9263.2011.00338.x.

Prater T, Marchant J, Vuorinen J. 1977. Guide to the identification and ageing of Holarctic waders. Tring: BTO.

Remisiewicz M, Avni J. 2011. Status of migrant and resident waders, and moult strategies of migrant waders using African inland wetland habitats, at Barberspan Bird Sanctuary in South Africa. Ibis 153:433-435. DOI: 10.1111/j.1474-919X.2011.01112_1.x.

Remisiewicz M, Wennerberg L. 2006. Differential migration strategies of the Wood Sandpiper (Tringa glareola) - genetic analyses reveal sex differences in morphology and spring migration phenology. Ornis Fennica 83:1-10.

Rensch B. 1950. Die Abhängigkeit der relativen Sexualdifferenz von der Körpergrösse. Bonner Zoologische Beiträge 1: 58-69.

Round PD, Pierce AJ, Dymond JN, Haque EU. 2012. Records of Little Stint Calidris minuta and Red-necked Stint C. ruficollis at Sonadia Island, Bangladesh. Stilt 61:55-56.

Storer RW. 1966. Sexual dimorphism and food habits in three North American Accipiters. Auk $83: 423-436$.

Székely T, Lislevand T, Figuerola J. 2007. Sexual size dimorphism in birds. In: Fairbairn, D.J., Blanckenhorn, W. \& Székely, T. (eds) Sex, Size and Gender Roles: Evolutionary Studies of Sexual Size Dimorphism:27-37. Oxford: Oxford University Press.

Székely T, Reynolds JD, Figuerola J. 2000. Sexual size dimorphism in shorebirds, gulls, and alcids: the influence of sexual and natural selection. Evolution 54:1404-1413. DOI: 
407

408

409

410

411

412

413

414

415

416

417

418

419

420

421

422

423

424

425

426

427

428

429

430

431

10.1111/j.0014-3820.2000.tb00572.x.

Tabachnick BG, Fidell LS. 1996. Using multivariate statistics. $3^{\text {rd }}$ ed. Harper Collins Publishers, New York, New York.

Titus K, Mosher JA. 1984. Chance-corrected classification for use in discriminant analysis: ecological application. The American Midland Naturalist 111:1-7.

Tomkovich PS, Soloviev MY. 1994. Site fidelity in High Arctic breeding waders. Ostrich 65:174-180. DOI: 10.1080/00306525.1994.9639680.

Tomkovich PS, Chih-Yuan P, Liu W. 2009. A unique record of a colour-flagged Little Stint in the East Asian-Australasian Flyway. Wader Study Group Bulletin 116:199-201.

Tree AJ. 1974. Ageing and sexing the Little Stint. Safring News 3:31-33.

Tulp I, Schekkerman H, Chylarecki P, Tomkovich P, Soloviev M, Bruinzeel L, Van Dijk K, Hildén O, Hötker H, Kania W, Van Roomen M, Sikora A, Summers R. 2002. Body mass patterns of Little Stints at different latitudes during incubation and chick-rearing. Ibis 144:122-134. DOI: 10.1046/j.0019-1019.2001.00014.x.

Underhill LG. 1997. Little Stint Calidris minuta. In: Harrison JA, Allan DG, Underhill LG, Herremans M, Tree AJ, Parker V, Brown CJ. The atlas of southern African birds. Vol. 1: Non-passerines: 420-421. BirdLife South Africa, Johannesburg.

Underhill LG, Prýs-Jones RP, Syroechkovski EE Jr, Groen NM, Karpov V, Lappo HG, van Roomen MWJ, Rybkin A, Schekkerman H, Spiekman H, Summers RW. 1993. Breeding of waders (Charadrii) and brent geese Branta bernicla bernicla at Pronchishcheva Lake, northeastern Taimyr, Russia, in a peak and a decreasing lemming year. Ibis 135: 277-292.

Underhill LG, Tree AJ, Oschadleus HD, Parker V. 1999. Review of ring recoveries of waterbirds in Southern Africa. Avian Demography Unit, University of Cape Town.

Zwarts L, Hulscher JB, Koopman K, Zegers PM. 1996. Discriminating the sex of Oystercatchers Haematopus ostralegus. Ardea 84A: 1-12. 


\section{Table $\mathbf{1}$ (on next page)}

Morphological features of adult male and female Little Stint.

$\mathrm{t}, \mathrm{p}$ - results of t-test comparing the sexes. $\mathrm{DI}_{\text {storer's }}$ - Storer's dimorphism index. 
Morphological features of adult male and female Little Stints

$t, p$ - results of t-test comparing the sexes; SDI-Storer's dimorphism index

\begin{tabular}{|c|c|c|c|c|c|c|c|c|c|}
\hline \multirow{2}{*}{ Measurement } & \multicolumn{3}{|c|}{ Females } & \multicolumn{3}{|c|}{ Males } & \multirow{2}{*}{$\mathrm{t}$} & \multirow{2}{*}{$\mathrm{p}$} & \multirow{2}{*}{ SDI } \\
\hline & $\mathrm{N}$ & Mean (SD) & Range & $\mathrm{N}$ & Mean (SD) & Range & & & \\
\hline \multicolumn{10}{|l|}{ Wing length $(\mathrm{mm})$} \\
\hline before primary moult & 70 & $99.9( \pm 2.2)$ & $95-104$ & 86 & $96.5( \pm 2.0)$ & $92-101$ & 10.32 & $<0.001$ & 3.46 \\
\hline after primary moult & 80 & $102.2( \pm 1.9)$ & $98-106$ & 77 & $98.4( \pm 2.0)$ & $94-102$ & 12.36 & $<0.001$ & 3.79 \\
\hline Total head length (mm) & 163 & $39.30( \pm 1.06)$ & $36.0-42.3$ & 185 & $38.26( \pm 0.98)$ & $35.8-41.1$ & 9.62 & $<0.001$ & 2.69 \\
\hline Bill length $(\mathrm{mm})$ & 163 & $18.11( \pm 0.92)$ & $16.3-20.5$ & 185 & $17.32( \pm 0.81)$ & $15.1-20.1$ & 8.55 & $<0.001$ & 4.48 \\
\hline Tarsus length (mm) & 162 & $22.09( \pm 0.86)$ & $19.7-24.2$ & 185 & $21.55( \pm 0.78)$ & $19.4-24.4$ & 6.16 & $<0.001$ & 2.47 \\
\hline Tarsus-plus-toe length (mm) & 163 & $40.94( \pm 1.27)$ & $37-44$ & 185 & $40.15( \pm 1.34)$ & $37-46$ & 5.69 & $<0.001$ & 1.96 \\
\hline Weight (g) & 162 & $24.48( \pm 3.66)$ & $19-42$ & 185 & $21.98( \pm 2.43)$ & $17-33$ & 7.42 & $<0.001$ & 10.78 \\
\hline
\end{tabular}

3 
Figure 1

Map of study area.

(A) Location of Barberspan and Leeupan Important Bird Area. (B) Outline of Barberspan and Leeupan lakes. Figure credit: Jacek Mazur.

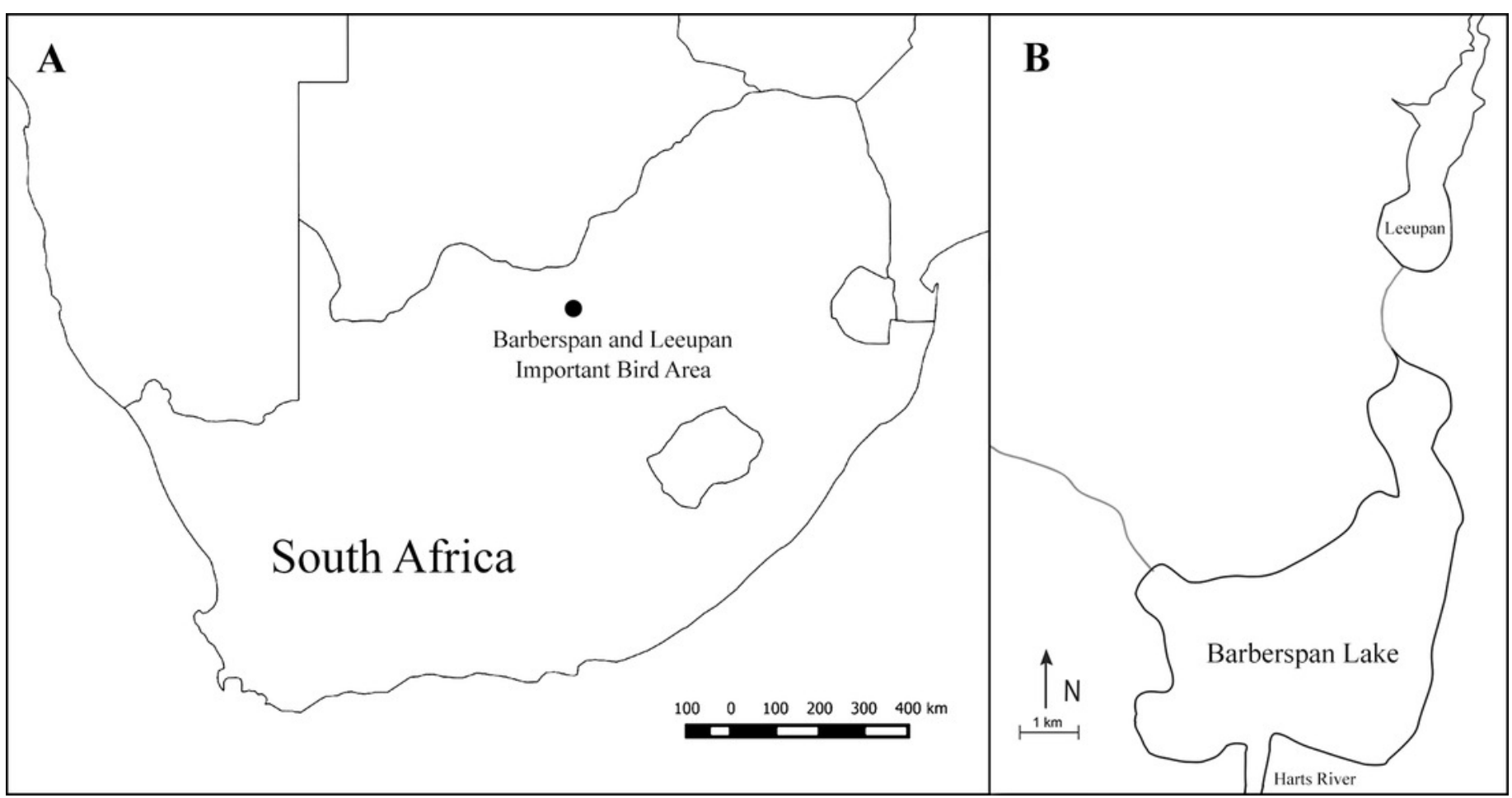


Figure 2

Probability of being a female in relation to the wing length according to the discriminant function analysis for Little Stints.

(A) Birds before primary moult ( $D_{1}$ function). (B) Birds after primary moult ( $D_{2}$ function).
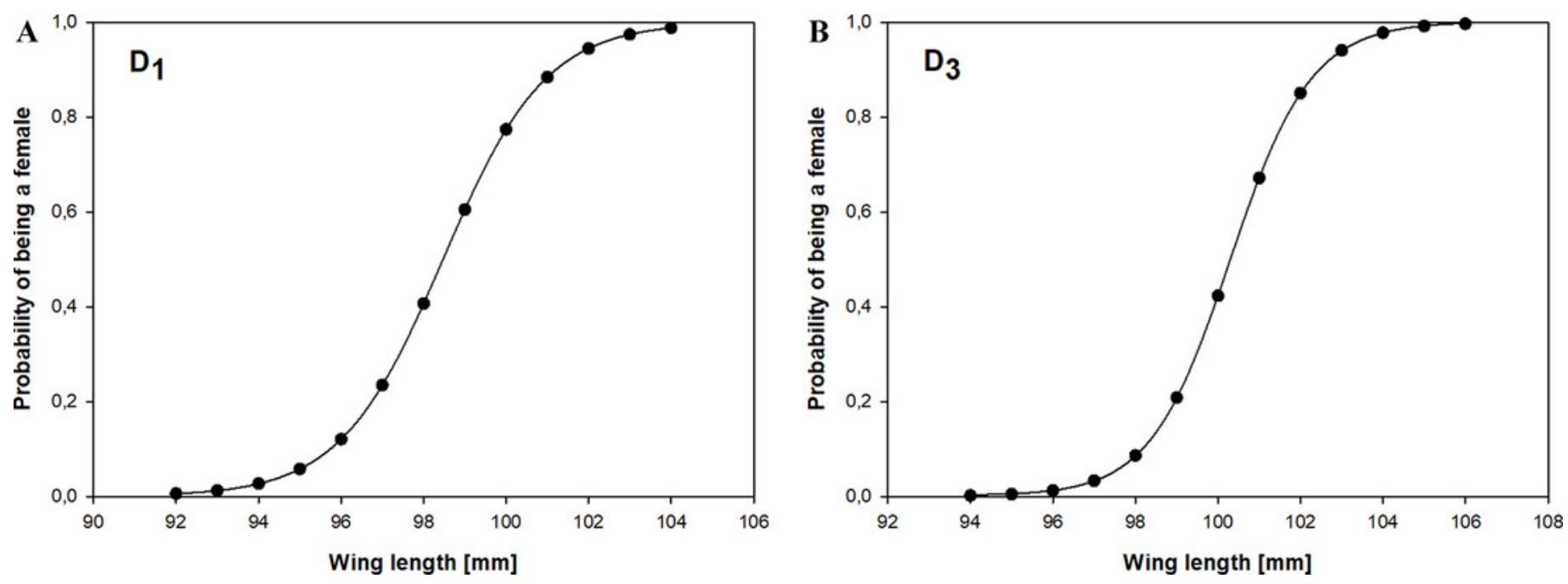
Figure 3

Probability of being a female in relation to the best combination of discriminating morphometric features for Little Stints.

(A) Birds before primary moult ( $D_{2}$ function). (B) Birds after primary moult ( $D_{4}$ function). Lines and values show the upper probability limits.
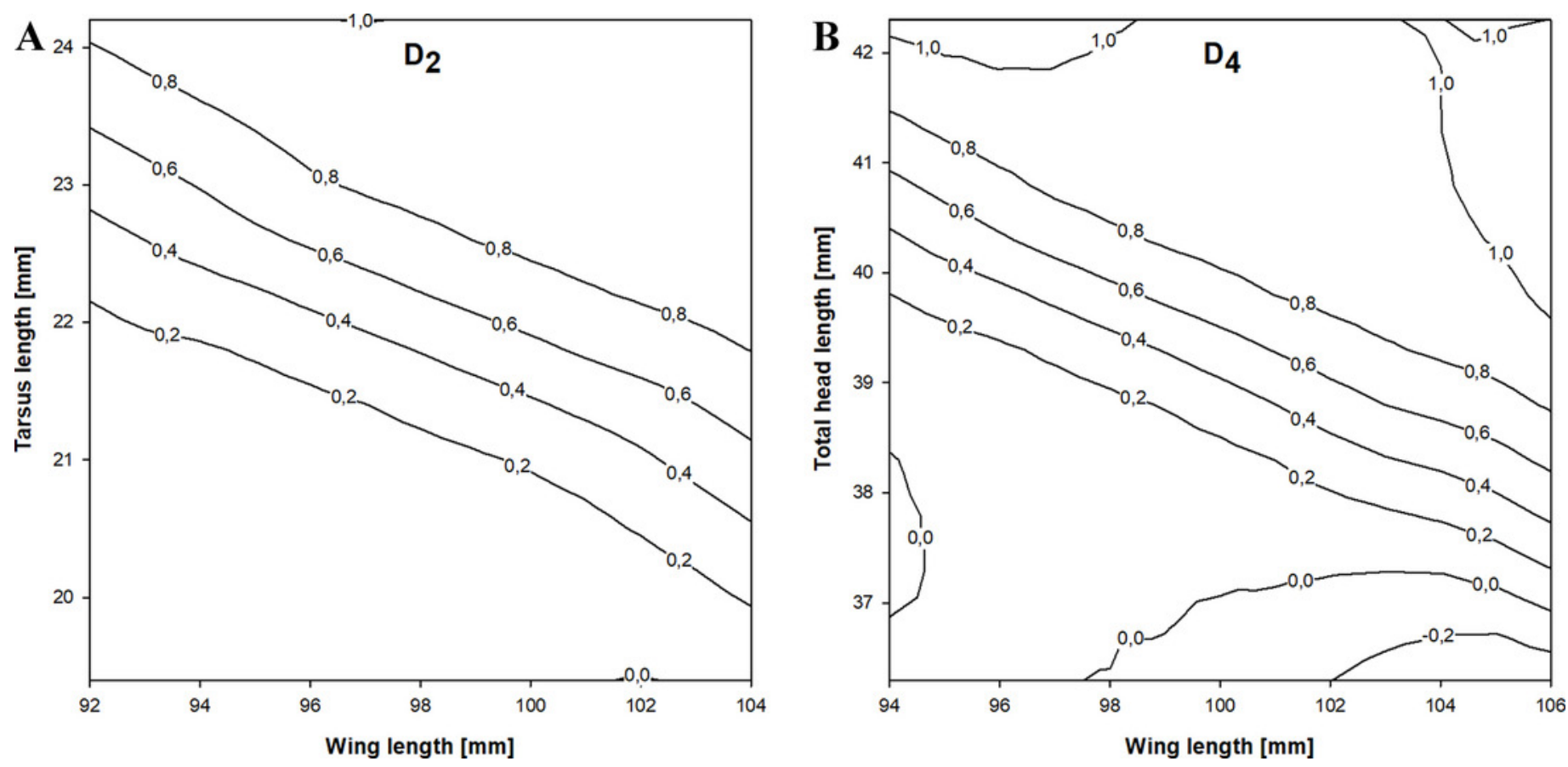